\title{
The Influence of Ethnicity on Customers' Choice of Banks: The Case of Selected Banks in Shashemene Town, Oromia, Ethiopia
}

\author{
Bewunetu Zewude \\ Paradise Valley College, Shashemene, Ethiopia
}

\begin{abstract}
The objective of this research was to explore the influence of ethnicity on customers' selection of banks in Shashemene town. A survey method was used in which quantitative data were gathered from 237 respondents selected based on convenient sampling technique. Data collected through a structured questionnaire were coded and entered in to SPSS version 20 where the analyzed data were presented using both descriptive and inferential statistical tools. It was found that $79.3 \%$ of respondents belong to the ethnic group (Oromo) to which the name of the banks (Oromia International Bank and Cooperative Bank of Oromia) is associated. Moreover, $25.7 \%$ of respondents answered that they were attracted to the bank because its name has something to do with their ethnic identity. Furthermore, $52.3 \%$ of respondents replied that the name of the bank and its association to their ethnic identity is a very necessary criterion to choose it at the beginning. Results of linear regression analysis also confirmed that people are increasingly attracted to the bank the name of which is associated to their ethnic identity $(0.312, \mathrm{P}<0.05)$. The role played by language in terms of motivating people to become customers of a given bank has also been pronounced in the current study. 5.1\% of survey participants replied that they were motivated to become customers of their present bank considering that their mother-tongue language is being commonly spoken among employees of the bank. Furthermore, ethnic-identity driven nomenclature of banks has also been found to influence the trust that people make on a given bank. Above all, it was found that about $25 \%$ of respondents revealed that they trust their current bank mainly because its name expresses their ethnic identity. Ethnicity influences customers' bank selection and the trust they bestow on it. The findings of the present study suggest that ethnicity affects individuals' economic behavior by making them to develop positive utility towards goods and services that belong to their own ethnic group.
\end{abstract}

Keywords: - economic behavior, ethnicity, bank, selection criteria, Shashemene

DOI: $10.7176 / \mathrm{JMCR} / 60-01$

Publication date:September $30^{\text {th }} 2019$

\section{Background of the study}

Every day life involves varied level of economic action and decision making for individuals, organizations, and the society at large. The motives behind such economic behaviors vary both between and among these different units of analysis. Financial sectors, particularly banks, are becoming highly competitive due to product differentiation, easiness of service availability, culture/religion based products offering and type of technology used in service delivery. Findings of previous studies revealed that customers select banks considering various features of the services. Almossawi (2001), found that reputation of a bank, friendliness of personnel working in a bank, availability and location of ATM machines, and the presence of adequate parking space as the factors affecting bank selection criteria employed by college students in Bahrain.

According to Rehman \& Saima (2008), higher qualification level makes bank customers more in favor of certain features that private and privatized banks are likely to offer. The influence of peer pressure has also been noted by other studies. Syed \& Guruswamy (2007) suggested that the majority of customers in Mekelle city seeking services from a retail bank make the choice based on other customers' recommendations. Tewolde (2015), undertook a study on features affecting customers bank service variety decision in Mekelle city of Ethiopia and found friendly or pleasing manners of staffs, bank receptions, and service quality, secure feeling at the bank, and number of branches to be the first five most important bank variety criteria.

The relationship between ethnicity and customers' economic decision making behavior has remained a topic of interest among researchers outside of Ethiopia since recent years. Findings of the researches thus far undertaken elsewhere in the world revealed a positive association between the two variables. For instance, Jamealla (2015), studied the influence of ethnicity on consumer behavior in Sidney, Australia, and found that inter-group differences affect the consumption of ethnic products, such as food, clothes, movies, and choice of service providers. Furthermore, Alexander (2008), researched ethnic minority consumer behavior in the UK and revealed that the combined effects of self-congruity, brand trust and brand attitude on brand loyalty showed a strong effect. Moreover, Safiek, et al (2010), made an exploratory study on ethnicity and choice criteria in retail banking in Malaysia and concluded that there is a difference in bank choice criteria based on ethnic backgrounds. With the exception of Asnake's (2014) attempt to write about the impact of ethnicity on economic development in Africa, no study has yet been conducted and published regarding the impact of ethnicity on customers' economic decision making behavior in Ethiopia. Therefore, this research has aimed at exploring the impact of 
ethnicity on customers' selection criteria of banks in Shashemene town, Ethiopia, with particular emphasis on Oromia International bank and Cooperative Bank of Oromia.

\section{Methods and Materials \\ Methods and data sources}

Primary data were collected using survey method. Survey method was used mainly to gather quantifiable data regarding the frequency of cases occurring and their patterns of distribution among the various segments of the study population. For this purpose, quantitative data were collected through a well prepared intervieweradministered questionnaire that was later translated in to locally understandable language, especially to make it suitable for enumerators. The questionnaire contained questions related to what customers take in to account when choosing a given bank. Data collectors were trained about the objectives and overall purpose of the research and made to be familiar with the data collection instruments and then guided about how to best approach respondents so as to collect quality data. The accuracy and relevance of the questionnaire was pretested using a pilot study on same study population but a different sample few days before starting the actual data collection activity. In addition, strict procedures of data quality management tasks were undertaken, especially through serious supervision and follow-up. Data collection activities were undertaken in June, 2019. Furthermore, existing literatures were intensively reviewed to supplement first-hand data sources. Accordingly, books, articles, both published and unpublished research findings, conference proceedings, and publications of international organizations were assessed and reviewed.

\section{Sample size and procedure}

With a very fluctuating number of customers, often switching from one to another, it was almost impossible to be able to obtain the exact number of customers in the banks where this study was undertaken. This implies that the sampling frame of the study's population from which accurate samples can be drawn using probability sampling technique was hardly found among the target banks. Consequently, convenience sampling method of the non-probability sampling cluster was used. First, Shashemene town was purposively selected due to accessibility of the town to the researcher which creates an easier way in to data gathering and frequent field visits. Moreover, the town is selected for the fact that it is one of the main strategic trade centers of Ethiopia, having all the gateways to the major regional cities and the capital of the country. Due to such geographic and demographic significances and the resulting lucrative business activities it hosts, the town has always been serving as one of the most preferred area to open branches and sub-branches of banks by investors. The abundance availability of various bank brands therefore, served as one of the reasons to choose Shashemene as the research site for the current study. The survey conveniently targeted customers of private banks the names of which are preceded by terms reflecting belongingness to a particular ethnic group, particularly Oromia International Bank and Cooperative Bank of Oromia. Customers of these banks were selected with the hypothesis that they might have preferred the banks for the mere reason that the nomenclature of the banks is associated to the ethnic enclave (Oromo) to which the customers are affiliated. Accordingly, 250 persons selected on the basis of convenience sampling technique were considered for the survey from which 237 cases were contacted making the response rate $94.8 \%$.

\section{Method of Data analysis}

After the data were collected, data cleaning and organization tasks were undertaken in order to check for completeness. It was then coded and entered in to SPSS version 20 for further processing. Both descriptive and inferential statistical tools, including frequency tables, charts and percentages, linear regression, chi-square tests, and cross tabulations were utilized to present frequencies and differential distribution of cases across the various sub-groups within the survey participants.

\section{Ethical Considerations}

The researcher has obtained ethical clearance from the concerned ethical approval committee of Wolaita Sodo University. An informed consent was gained by informing the research participants about the objectives and rationale of undertaking the research. Furthermore, up on collecting data, respondents were given an oral orientation not to write their names on the questionnaire in order to keep their personal identity anonymous. The researcher further ensured this by not indicating the exact names of any of the respondents. Above all, each respondent was informed about the level of freedom that is provided in case one wants to withdraw from the research. 


\section{Results and discussion}

Socio-demographic characteristics of respondents

Table 1: frequency distribution of respondents based on their socio-demographic characteristics

$\begin{array}{ccc}\text { Variables } & \text { Categories } & \text { Frequency (\%) } \\ \text { Mex } & \text { Fele } & 173(73.0 \%) \\ & \text { Female } & 64(27.0 \%) \\ \text { Age } & 1-20 & 23(9.7 \%) \\ & 21-30 & 112(47.3 \%) \\ \text { Ethnicity } & 31-40 & 69(29.1 \%) \\ & 41-50 & 18(7.6 \%) \\ & 51-60 & 13(5.5) \\ \text { Residential background } & \geq 61 & 2(0.8 \%) \\ \text { (raised-up area) } & \text { Oromo } & 188(79.3 \%) \\ & \text { Amhara } & 19(8.0 \%) \\ & \text { SNNPs } & 17(7.2 \%) \\ \text { Tigray } & 2(0.8 \%) \\ \text { Religion } & \text { Other } & 11(4.6 \%) \\ & \text { Rural } & 103(43.5 \%) \\ & \text { Urban } & 134(56.5 \%) \\ & \text { Orthodox Christian } & 56(23.6 \%) \\ & \text { Muslim } & 115(48.5 \%) \\ & \text { Protestant } & 53(22.4 \%) \\ & \text { Catholic } & 7(3.0 \%) \\ & \text { Non-believers } & 1(0.4 \%) \\ & \text { Others } & 5(2.1 \%) \\ & \text { BA/Sc degree } & 2(0.8 \%) \\ & \text { Tetal } & 33(13.9 \%) \\ & \text { Never attended school } & 57(24.1 \%) \\ & 1-4 & 27(11.4 \%) \\ & 5-8 & 51(17.3 \%) \\ & 9-10 & 14(5.9 \%) \\ & 11-12 & \end{array}$

\section{Source: survey data, 2019}

As shown in table 1, most of the respondents are male (73\%) whereas the remaining (27\%) are females. Moreover, 112 of 237 respondents are between 21-30 years old while people 61 and above years of age constitute relatively the smallest percentage $(0.8 \%)$ in the distribution. In terms of ethnicity, respondents that belong to the oromo ethnic group take the lion's share $(79.3 \%)$ and those who claim to belong to the tigray ethnic group consist $0.8 \%$ of the respondents. $56.5 \%$ of survey respondents replied that their residential (raisedup) area is urban and $43.5 \%$ answered to have a rural residential background. Furthermore, Muslims constitute the largest (48.5\%) share of respondents followed by orthodox Christians (23.6\%). Above all, respondents educated both grade 9-10 and possessing BA/Sc degree make up the largest frequency in the distribution whereas those that have never attended school got the least share $(0.8 \%)$. 


\section{The impact of Ethnicity on customers' bank selection}

Table 2: factors that motivated customers when choosing the bank at which they are customers

Nomenclature of the bank related to customers' ethnicity

knowing employees

$61(25.7 \%)$

Advertisement

language mostly spoken in the bank

informed about its better service

$12(5.1 \%)$

number of branches

$65(27.4 \%)$

relatives/friends previously customers

$6(2.5 \%)$

physical proximity

$13(5.5 \%)$

receive salary through the bank

$14(5.9 \%)$

accidental/unplanned

$11(4.6 \%)$

other

$21(8.9 \%)$

$1(0.4 \%)$

Total (N)

$237(\mathbf{1 0 0 . 0 \% )}$

Source: survey data, 2019

Table 2 reveals the responses of survey participants when asked about what motivated them to become customers of their current bank in the first instance. It is shown that $25.7 \%$ of respondents replied that they have chosen the current bank because the nomenclature of the bank is associated to the ethnic group to which they are subscribed. Furthermore, $8 \%$ of survey participants disclosed that the presence of employees they know in the bank was the factor that motivated them to become customers of the current bank. The language that is commonly spoken among the employees of the bank has also served as the other factor predisposing customers to choose the bank $(5.1 \%)$. Moreover, $27.4 \%$ of respondents answered that they have chosen their current bank having been informed about the relatively better service that the bank provides. Above all, the choice of the current bank was accidental for $8.9 \%$ of respondents.

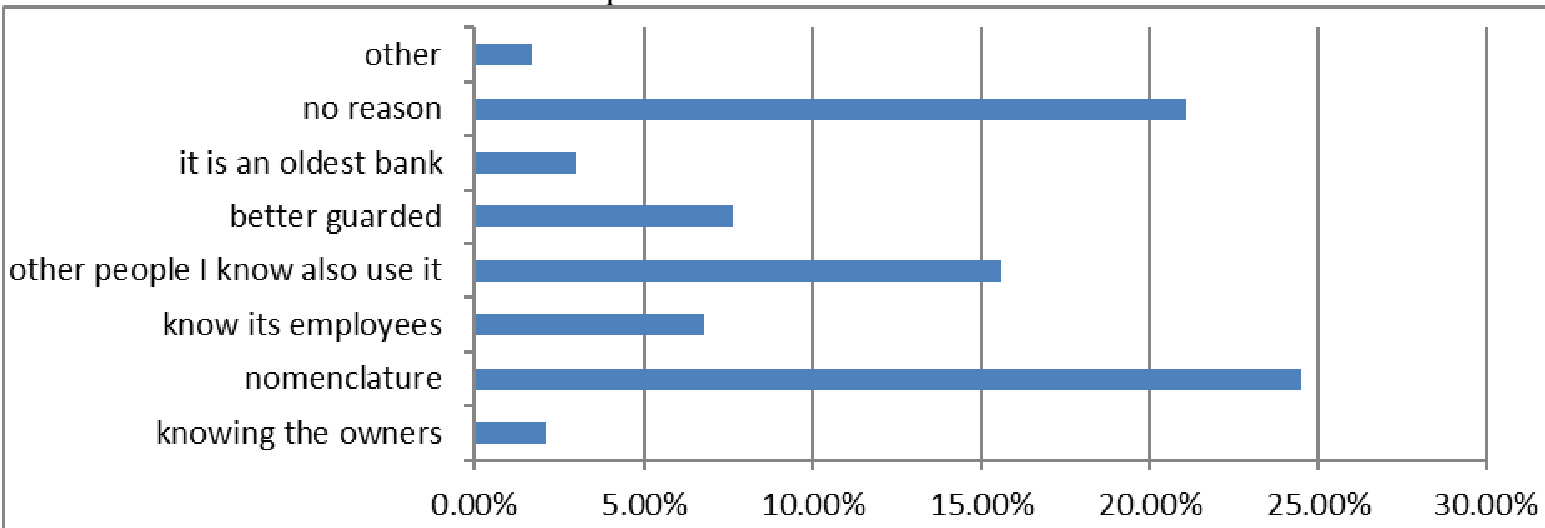

chart 1: respondents' reason to trust their current bank

Data from the present survey revealed that $80.6 \%$ of respondents trust the current bank more than other banks in the surrounding. Chart 1 shows their reason to trust the bank at which they are currently customers more than other banks. Accordingly, it is found that $24.5 \%$ of respondents replied that they trust the bank due to the fact that they have a high sense of belongingness to the bank because its name has something to do with their ethnic identity. Moreover, $21.1 \%$ of respondents trust the bank for no reason. In addition, $15.6 \%$ answered that they trust the bank since other people they know also use it.

Respondents were also given the criteria that they probably take in to account when selecting a given bank and asked to rate the level of importance they attach to these conditions on a scale that ranges from very necessary to unnecessary. The criteria include the bank having high interest rate on saving, low interest rate on loan, language commonly spoken in the bank, the name of the bank associated to their ethnic identity, the bank's number of branches, the bank's relative location, its proximity to home or work place, and other related variables. As presented in chart $2,52.3 \%$ of respondents replied that they consider the link between the name of the bank and their ethnic identity as very necessary to become a customer of a given bank whereas it is only $7.2 \%$ of the respondents that answered such criterion is unnecessary. In addition, their mother-tongue language being spoken in the bank is very necessary for $54 \%$ of respondents as a condition to choose a given bank. 


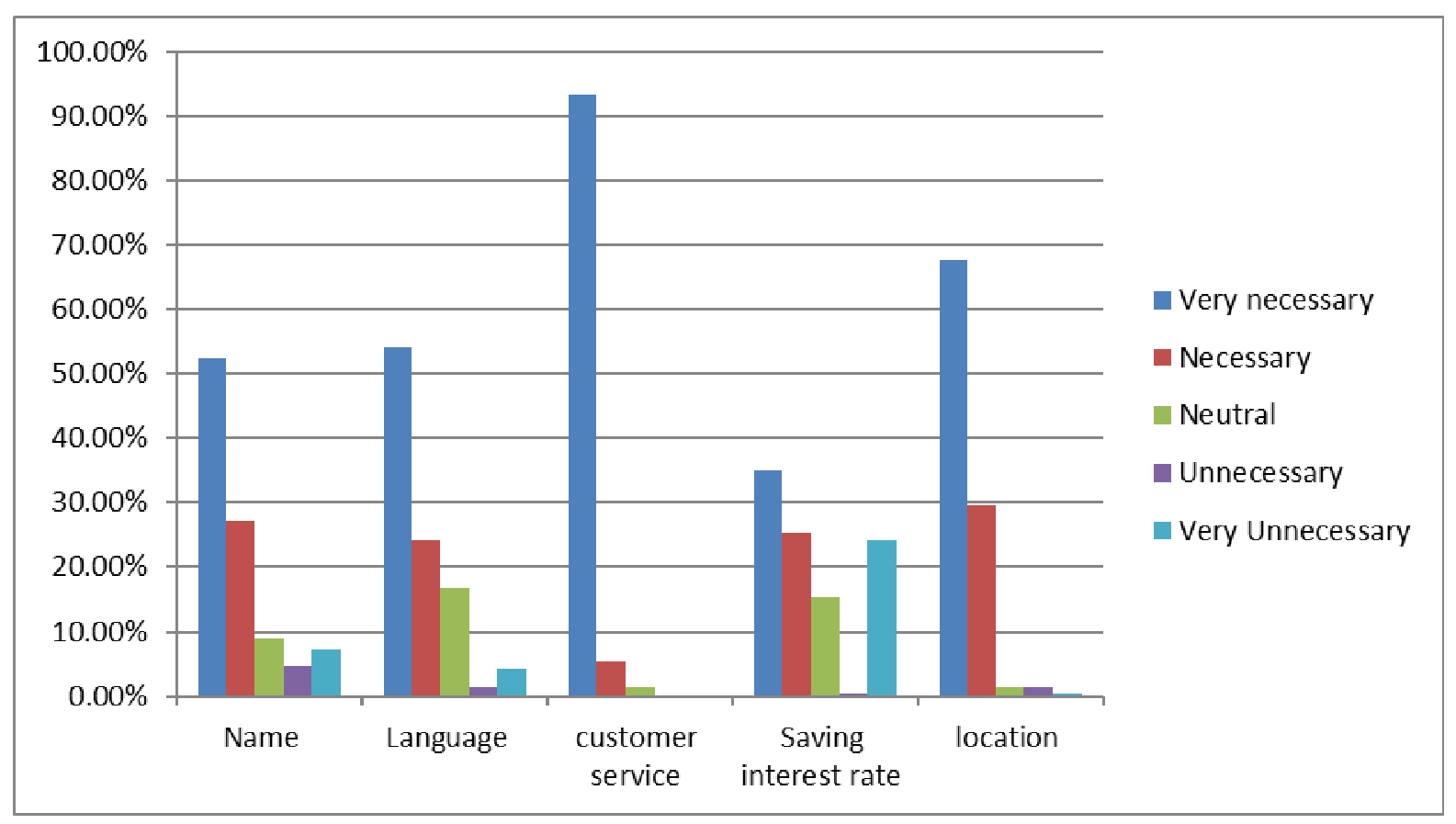

Table 3: a linear regression between socio-demographic variables and choice criteria

\begin{tabular}{|c|c|c|c|c|c|c|c|}
\hline \multirow[t]{2}{*}{ Model } & \multicolumn{2}{|c|}{ Unstandardized Coefficients } & $\begin{array}{c}\text { Standardized } \\
\text { Coefficients }\end{array}$ & \multirow[t]{2}{*}{$\mathrm{t}$} & \multirow[t]{2}{*}{ Sig. } & \multicolumn{2}{|c|}{$\begin{array}{l}95.0 \% \text { Confidence Interval } \\
\text { for B } \\
\end{array}$} \\
\hline & $\mathrm{B}$ & Std. Error & Beta & & & Lower Bound & Upper Bound \\
\hline (Constant) & 1.136 & .474 & & 2.396 & .017 & .202 & 2.069 \\
\hline Sex & .074 & .167 & .028 & .443 & .658 & -.255 & .403 \\
\hline Age & -.016 & .076 & -.014 & -.216 & .829 & -.167 & .134 \\
\hline educational status & .113 & .045 & .157 & 2.499 & .013 & .024 & .20 \\
\hline $\begin{array}{l}\text { residential } \\
\text { background }\end{array}$ & -.180 & .159 & -.075 & -1.129 & .260 & -.493 & .13 \\
\hline Ethnicity & .312 & .064 & .306 & 4.899 & .000 & .186 & .437 \\
\hline Religion & -.049 & .077 & -.039 & -.633 & .527 & -.201 & .103 \\
\hline
\end{tabular}

a. Dependent Variable: nomenclature of the bank

Table 3 shows a linear regression between respondents' socio-demographic variables and considering the link between the nomenclature of the bank and their ethnic identity as necessary criterion for choosing a bank. It is found that ethnicity significantly affects customers to consider the association between the name of the bank and their ethnic identity as a necessary criterion to choose the bank. The positive value of beta (.312) further reveals a linear relationship between the two variables. The association between the variables has also been further elaborated in the cross-tabulation and chi-square test analysis below in table 4 below. This might have resulted mainly due to the fact that the significant majorities (188 of 237) of respondents belong to an ethnic group (Oromo) that is associated to the nomenclature of the banks where the study was undertaken (Oromia International Bank and Cooperative bank of Oromia). 
Table 4: ethnicity * nomenclature of the bank Cross tabulation

Count

\begin{tabular}{|c|c|c|c|c|c|c|c|}
\hline & \multicolumn{5}{|c|}{ nomenclature of the bank } & \multirow[t]{2}{*}{ Total } \\
\hline & & very necessary & Necessary & neutral & Unnecessary & Very unnecessary & \\
\hline \multirow{5}{*}{ ethnicity } & Oromo & 110 & 50 & 12 & 5 & 11 & 188 \\
\hline & Amhara & 9 & 8 & 2 & 0 & 0 & 19 \\
\hline & SNNPs & 3 & 4 & 3 & 3 & 4 & 17 \\
\hline & Tigray & 0 & 0 & 1 & 1 & 0 & 2 \\
\hline & other & 2 & 2 & 3 & 2 & 2 & 11 \\
\hline Total & & 124 & 64 & 21 & 11 & 17 & 237 \\
\hline
\end{tabular}

Chi-Square Tests

\begin{tabular}{|l|r|r|r|}
\hline & Value & df & Asymp. Sig. (2-sided) \\
\hline Pearson Chi-Square & $54.332^{\mathrm{a}}$ & 16 & .000 \\
Likelihood Ratio & 43.520 & 16 & .000 \\
Linear-by-Linear Association & 24.768 & 1 & .000 \\
N of Valid Cases & 237 & & \\
\hline
\end{tabular}

a. 16 cells $(64.0 \%)$ have expected count less than 5 . The minimum expected count is .09 .

According to the data presented in table 4, ethnicity also significantly determines customers' consideration of language to be the main criterion in the process of choosing a given bank.

Table 5: a linear regression between socio-demographic variables and choice criteria

\begin{tabular}{|c|c|c|c|c|c|c|c|c|}
\hline \multirow{2}{*}{\multicolumn{2}{|c|}{ Model }} & \multicolumn{2}{|c|}{$\begin{array}{c}\text { Unstandardized } \\
\text { Coefficients }\end{array}$} & $\begin{array}{l}\text { Standardized } \\
\text { Coefficients }\end{array}$ & \multirow[t]{2}{*}{$\mathrm{t}$} & \multirow[t]{2}{*}{ Sig. } & \multicolumn{2}{|c|}{$\begin{array}{l}95.0 \% \text { Confidence } \\
\text { Interval for B }\end{array}$} \\
\hline & & $\mathrm{B}$ & $\begin{array}{l}\text { Std. } \\
\text { Error }\end{array}$ & Beta & & & $\begin{array}{l}\text { Lower } \\
\text { Bound }\end{array}$ & $\begin{array}{l}\text { Upper } \\
\text { Bound }\end{array}$ \\
\hline \multirow{7}{*}{1} & (Constant) & 1.515 & .438 & & 3.459 & .001 & .652 & 2.379 \\
\hline & Sex & -.138 & .154 & -.059 & -.891 & .374 & -.442 & .167 \\
\hline & Age & .003 & .071 & .002 & .036 & .972 & -.137 & .142 \\
\hline & educational status & .012 & .042 & .019 & .279 & .780 & -.070 & .094 \\
\hline & residential background & .101 & .147 & .048 & .685 & .494 & -.189 & .390 \\
\hline & Ethnicity & .169 & .059 & .190 & 2.873 & .004 & .053 & .285 \\
\hline & Religion & -.012 & .071 & -.011 & -.169 & .866 & -.152 & .128 \\
\hline
\end{tabular}

a. Dependent Variable: employees of the bank speak similar language with you

\section{Discussion}

The influence of ethnicity on customers' economic decision making behavior has been studied by researchers (e.g. Mafune, et al (2013); Lili (2014); Srinivasan, et al (2014)) outside of Ethiopia the results of which reveal a positive association. For instance, Jamealla (2015) studied the influence of ethnicity on consumer behavior in Sidney, Australia and found that inter-group differences affect the consumption of ethnic products, such as food, clothes, movies, and choice of service providers. In addition, Antoinette, et al (2008), undertook a study on the importance of ethnic networks for business transactions of small enterprises and concluded that ethnicity plays an essential role in determining the fate of business transactions and features of contractual agreements.

The findings of the present survey revealed that ethnic-identity based nomenclature of commercial banks in the study area has appeared to be a successful marketing strategy. It is found that $25.7 \%$ of respondents in the survey answered that they were attracted to the bank because its name has something to do with their ethnic identity. In addition, $52.3 \%$ of respondents answered that the name of the bank and its association to their ethnic identity is a very necessary criterion to choose it to become its customer. The role played by language in terms of motivating people to become customers of a given bank has also been pronounced in the current study. As shown in table $2,5.1 \%$ of survey participants replied that they were motivated to become customers of their present bank considering that their mother-tongue language is being commonly spoken among employees of the bank. Furthermore, ethnic-identity based nomenclature of banks has also been found to influence the trust that people make on a given bank. As indicated, about $25 \%$ of respondents revealed that they trust their current bank mainly because its name expresses their ethnic identity.

The findings of the present research are consistent with Alexander's (2008) study. He researched ethnic 
minority consumer behavior in the UK and revealed that the combined effects of self-congruity, brand trust and brand attitude on brand loyalty showed a strong effect. Moreover, Safiek, et al (2010), made an exploratory study on ethnicity and choice criteria in retail banking in Malaysia and concluded that there is a difference in bank choice criteria based on ethnic backgrounds.

The present research contains findings that are different from many other studies thus far undertaken by other researchers in Ethiopia. Perhaps, this might be mainly due to the fact that ethnicity and ethnic-oriented nomenclature of banks has never been the subject of those studies. Rather, the focus has always been on service quality and other related features of banks and the influence of such variables on customers' choice. For instance, Metasebiya and Tesfaye (2017) studied determinants of bank selection choices and customer loyalty in Ethiopian banking sector and found that the speed of the services, the adequacy of content of the branch network, the appropriateness of location of branches, easiness of getting forex services in the bank, service quality and availability, accessibility of both physical and human resources significantly affect customers' choice of commercial banks in Ethiopia. In addition, Kebede (2017), researched determinants and outcome of customer satisfaction at commercial bank of Ethiopia and found out that services quality, services features, and customer compliant handling system were the major determinants of customer satisfaction in commercial bank of Ethiopia. In other ways, the present study coincides with the findings of these researches in the sense that $93.3 \%$ of respondents in the survey replied that fast and attractive customer service is a very necessary criteria when choosing a given bank as shown in chart 2 above.

\section{Conclusion}

The purpose of the present study was to examine the influence of ethnicity on customers' choice of a given bank in Shashemene town, Ethiopia. Quantitative data were collected using an interviewer administered questionnaire from 237 respondents conveniently selected from Oromia International Bank and Oromia Cooperative Banks in June, 2019. Data were then inserted in to SPSS version 20 and analyzed mainly using descriptive statistical techniques. According to the data, ethnicity has been an important variable that influences customers' selection of a given bank. The association between the name of the bank and the ethnic identity of customers not only motivates customers to choose a given bank, but also affects their trust on the bank. Furthermore, ethnicity has been found to be one of the very necessary conditions that people take in to consideration when selecting a given bank along with other variables such as quality of customer services, the relative location of the bank, and interest rate on saving.

\section{References}

Alexander Albert. K. (2008). Ethnic Minority Consumer Behavior: A study of brand loyalty and its antecedents in the UK. A thesis submitted to Cardiff University in partial fulfillment for the degree of doctor of philosophy.

Almossawi, M. (2001). "Bank Selection Criteria Employed by College Students in Bahrain": An Empirical Analysis. International Journal of Bank Marketing, 19(3), 115-25.

Antoinette S., Raj Kamal L., Sandya K. (2008). Importance of Ethnic Networks for Business Transactions of the Small Enterprises. Institute for Financial Management and Research Small Enterprise Finance Centre

Asnake Anteneh. (2014). Ethnicity and its impact on economic development in Africa: case studies from Ethiopia and Nigeria. Unpublished thesis submitted to Addis Ababa University, school of graduate studies, in partial fulfillment for the requirements of obtaining Masters Degree in African Studies.

Jamealla V Intharacks. (2016). The Influence of Ethnicity on Consumer Behavior: A study of inter-generational and inter-group differences. Unpublished dissertation paper submitted to Western Sydney University in partial fulfillment for the degree of doctor of philosophy.

Kebede Teshale Shode. (2017). Determinants and outcome of customer satisfaction at the commercial bank of Ethiopia: Evidence from Addis Ababa. African Journal of Marketing Management, Vol. 9(7), pp. 107-119, DOI: 10.5897/AJMM2016.0509, ISSN2141-2421

Lili Gai. (2014). Dinning at ethnic- themed restaurants: an investigation of consumers' ethnic experiences, preference formation, and patronage, A thesis submitted to University of North Texas in partial fulfillment for the degree of doctor of philosophy.

Meftune Ozbakir, Meltem Nurtanis, Sureyya Karsu. (2013). Purchasing behaviors of the consumers based on ethnic identities in Turkey. Journal of management and marketing research

Metasebiay Boru Lelissa, Tesfaye Boru Lelissa. (2017). Determinants of Bank Selection Choices and Customer Loyalty, the Case of Ethiopian Banking Sector (Full Length Paper). European Journal of Business and Management ISSN 2222-1905 ISSN 2222-2839 Vol.9, No.13,

Rehman, H.U., \& Saima, A. (2008). An empirical analysis of the determinants of bank selection in Pakistan: A customer view. Pakistan economic and social review, volume 46, No. 2.

Safiek M., Kuala T., Nik Hazimah N., Hayatul S., (2010). Ethnicity and choice criteria in retail banking: a 
Malaysian perspective. International journal of business and management, Vol. 5, No.6

Srinivasan, R., Srinivastava R.K., Sandeep B. (2014). Influence of ethnicity on uniqueness and snob value in purchase behavior of luxury brands. Journal of research in marketing, Vol. 2, No. 3

Syed, A. M., \& Guruswamy, D. (2007). Customer preferences for retail banking services in Ethiopia: with special reference to retail banks in Mekelle City.

Tewolde Fisahaye. (2015). Assessment on Features Affecting Customers Bank Service Variety Decision, Case study of United Bank, Mekelle Branch. International Journal of Scientific and Research Publications, Volume 5, Issue 5, ISSN 2250-3153 